\title{
Development of Blended Learning Learning Model in Equality Education Package B Program in Improving Learning Motivation in Sanggar Kegiatan Belajar Kabupaten Bogor
}

\author{
Mohammad Givi Efgivia \\ Faculty of Teacher Training and Education, University of Ibn Khaldun, Bogor \\ mgivi@uika-bogor.ac.id
}

\begin{abstract}
The purpose of this study is to find learning styles that can increase student learning motivation in Package B. Options that lead to the achievement of these goals by developing integrated learning models that focus on students' learning motivation. Develop a learning model based on facts and ideas about the learning process that is applied about ordinary applications. The blended learning model in package B is carried out through research and development through three steps: initial studies, conceptual modeling, and experiments to determine the effectiveness of the model. The results found that the blended learning model was effective in increasing students' motivation in program B at the SKB Kabupaten Bogor.
\end{abstract}

Keywords: blended learning, learning model and learning motivation

\section{Introduction}

School equivalency degree in education is an alternative pathway outside formal schooling. Although the alternative is considered a non-formal education, the graduates' competency is equally competitive based on the test conducted by an accredited institution under the education law. Community's perspective regarding school equivalency degree tends to be unsupportive due to common students' social background that enrolled to equivalency degree. On the contrary, the degree option contributes a large number of gross enrollment rate (GER) and the general participation rate (GPR) at all levels of school equivalency degree; for instance, Package A, Package B, and Package C [1].

School equivalency degree is always overshadowed by formal education which utilising the resources of teachers, with teacher-centered teaching model. However, the characteristics of school equivalency degree are very diverse in terms of business model, income level, regional location, and socio-cultural. Students of equivalency degree characteristics are significantly different compared to formal school students as they are required to be more independent and learn things on their own pace. This also shows that school equivalency degree students enroll to the degree on their own will rather than being forced to enroll in formal school [2].

Students of school equivalency degree generally came from a lower social class that need to be educated on how school equivalency operates. However, prospective students of the degree nowadays are students that coming from relatively middle and upper class with an outstanding academic ability. Most reasons of students enrolled to school equivalency degree 
is because they want a flexibility on studying time and focusing more on the practicality of the courses. As a result, school equivalency degree committees has been working on providing tutors and teachers who have competence of knowledge, learning models, and computer literacy and technology in operating Package A, Package B, and Package C. For instance, Package B program now has operates fully on software e-learning [3].

The main basis of the study comes from the research by Didaly Islam Main and Charles A Lubber [4] that investigated online resources accessibility by farmers in Bangladesh. The aims and objectives of this research are to gain a deeper understanding into the accessibility and use of farmers' information by taking the theme of "Innovation diffusion" in the form of Roger into a theoretical framework that becomes a method of collecting data using both qualitative and quantitative techniques. Questionnaires as part of quantitative data collected from respondents while qualitative data was carried out by conducting interviews with farmers' interviews. The instructor is informed to examine the pattern of their service to the farmers. This research resulted that almost all farmers involved in the study lacked the closeness of information sources in the beginning, which conducted online through the system due to technical debts. Farmers believed that there is a concern about using online computers. Also, they mentioned that the underlying issue is that their products are undervalued compared to other products such as seed, fuel, pesticides, and transportation.

To improve students' motivation and optimise the learning process, teachers are encouraged to be assistants, resource liaison, and solution providers [5]. The motivation will encourage students to have a desire to succeed, learn, and have a realistic future goals [6]. Social presence is generally considered important in learning process based on research conducted by Rosemarie Garner and Elizabeth Rouse. Australian agenda state reforms for early childhood education and treatment have resulted in an improvement in the need for quality early childhood teachers. Universities have developed a new method of providing education programs for preschoolers which designed to support quality education diplomas for their teaching qualifications. Investigating from both community e-learning systems and oneto-one exercises, this study concludes that the combination of contact and social status in the online learning environment has a significant influence in improving students' motivation. Furthermore, another model of blended learning face-to-face learning using interactive CDs and e-books on the internet. A study conducted by Gilian Lord and Lara Lomicka [7] mentioned that the development of online communities is not only applicable for distance education hybrid program, but also to combine distance learning with the original level. This is often called as a hybrid program as it combines many types of instruction. Various tools for interacting and chatting are combining learning that mixturing with traditional classes. Not only that online learning has a lot of convenience, but also it does not lose the essence of having face-to-face meaning.

Rosemarie Garner and Elizabeth Rouse mentioned on their paper that Australian state's agenda reformed for early childhood education and treatment have resulted in an improvement of the teachers. Many universities have developed a new method of providing educational programs for preschoolers specifically for their qualifications. Through e-learning systems and one-on-one exercises, this study concluded that the combination of contact and social status in the online learning environment has massively influenced the quality of the learning process. Additionally, Lord and Lomicka stated that development of online communities is not only supportive for distance education hybrid programs, but also applicable in other types of learning which involve many types of instruction. This type of hybrid program is believed to not reduce the essence of having a face-to-face traditional classes' fundamental value [7]. 
Blended learning is a learning method that integrating online learning experience into traditional face-to-face learning. This approach has been widely accepted among educational institutions and practitioners. Throne argued that one of the advantages of this approach is to promote students' engagement. Furthermore, the accessibility and flexibility aspects of blended learning are considered as the next positive impact of this learning type. The implementation of this learning consisted of uploading course material, online assignments and quizzes, student-teacher interaction and collaborative work [8].

Bersin added that blended learning is a combination of various types of training platforms (technology, activities and event's type) to create an optimal training program for specific attendees. The term blended means traditional instructor-led training in electronic format. In the book's context, mixed learning programs utilise various forms of e-learning, which also supplementing with instructor training [9].

Assessing through the previous paragraph, it is concluded that blended learning is a combination of technology, media, activities and activities' types to create a training program that is most suitable for a different group of participants. This learning program maximises the uses of various forms of quality e-learning and training instructors to get the essence of traditional face-to-face and e-learning experiences.

More specifically, Aly showed empirical aspects from three different types of learning; namely (1) face-to-face (2) Online or e-learning, and (3) blended learning in the subject of management accounting [10]. This study compared mid-semester and final exam results taught by the same instructor or teacher through different platforms aforementioned. Surprisingly, there was no significant difference in terms of the result among those three learning platform types. Thus, he concluded that teachers' quality and teaching methods are more important than learning platform. Though, he added that teachers or instructors must focus on the user interface and content quality when delivering lectures or materials.

Chen and Yao studied about the level of blended learning student satisfaction. Their research focused on main factors which influenced students satisfaction. There were six dimensions involved in an integrated learning environments which were evaluated; namely, students, professors, courses, technology, design, and environments. Their study found that course design was the most influential factor of satisfaction. Thus, they believed that institutions need to focus on course design and their concrete plan to implement blended learning [11].

Blended learning has also been proven effective in some case studies. Isa [12] evaluated the excellence of blended learning through a research which showed that the development of integrated learning is able to improve student learning outcomes and tend to be fairly straightforward for students to be digested. Main focuses on this study are as follows: (1) What is the conceptual learning model? Combining learning to increase students' eagerness assessing through students enrolling package B program. (2) How to use mixed learning styles to increase learning motivation for students enrolling package B program. (3) Whether effective learning style for blended learning increasing students' independence among students enrolling package B program in Bogor Learning Activity Studio (SKB).

To achieve the objectives mentioned in the previous paragraph, this research will be following guidelines of educational research and development. Research and development is the process of developing and examining educational products in the form of learning objectives how to evaluate hardware, software, or method. 


\section{Research Method}

Research and development primarily utilises three methods; namely survey, evaluative, and experimental [13]. Survey is used in preliminary research to determine the supporting conditions and practices associated with the product that needs to be developed. Experimental refers to design the pre-experiment, which in the case using One Group Pretest-Posttest design. The measured outcome is the independence of students' learning by assessing the learning outcomes provided the test before (pretest), the test after the use of interactive CD media and e-books (pretest), using the same course material. The results of the initial test (pretest) will be compared to the final test (posttest). The experimental design consists of one class of experimental groups. The selection of the experimental class depends on the objectives and characteristics which previously established.

Operational procedures taken on this research are as follows: (1) a preliminary study (2) preparation of conceptual models and (3) testing the effectiveness of learning models. Firstly, a preliminary study was conducted to discover and explore the existing learning models in several institutions providing school equivalency degree program in Bogor Regency, such as Bogor Regency SKB. Aspects which were explored in this annual study included: (1) current learning models of package B programs (2) learning methods and strategies applied by institution or tutors (3) students activities (4) tutors' role in managing and operating learning activities (5) learning activities proposed by students (6) activities assessment in learning and lastly (7) following up learning.

The conceptual model development is carried out by determining components' model based on theoretical information and validation from both experts and practitioners. Component model is decided by examining the results of preliminary studies and previous field exploration. This is achieved by drawing prescriptions from a literature review of learning models, specifically both theory and practice of learning in the institution who organises package B program. The development of tools and substance of the model is carried out by identifying devices and model's content, model's substance, expert validation, and testing of model's devices. Identification of the device and substance of the model is conducted by analysing the characteristics of blended learning and analyse the correlation with the independence learning demonstrated by students. The trial of the model set was conducted using the limited field-trial method collaborating with several institutions that organise package B programs in Bogor District SKB.

Wider model trials have been done repetitively to assess the effectiveness of the model based on the opinion of Hopkins and Ahtaridou which involved activities as follows: (1) planning of learning implementation strategies (2) implementation of learning (3) reflection of results and processes learning and (4) observation and improvement of the learning process. This learning cycle involves two cycles of learning; namely implementation with different students and different learning institutions. The first was conducted at the Multimedia Laboratory of Educational Technology Study Programs in UIKA Bogor Campus, while the second was conducted at the Learning Activities Studio. Thus, the variation and accuracy of data sets should be sufficient enough to conduct this study which aims to improve the learning model that is effective in improving students' independence in the learning.

This research is conducted both qualitatively and quantitatively towards the implementation of the learning model. While qualitative analysis is conducted to describe the results of preliminary research, quantitative analysis is conducted to relate the feasibility and influence of the developed model which achieved by statistical analysis [14]. In analysis data sets to produce outcome, there are activities involved including grouping data sets based on 
variables and types of respondents, tabulating data bases on variables from all respondents, presenting data for each variable studied, calculating the outcome to answer formulation's problem and challenging hypotheses that have been proposed.

Analysing data sets by challenging hypothesis using tests of similarity of two averages: the two-party test which are pretest and posttest data. The $t$ formula is compared with $t 1-\alpha$, where $t 1-\alpha$ is obtained from the list of distributions with odds $(1-\alpha)$ and $\mathrm{dk}=(\mathrm{n} 1+\mathrm{n} 2-2)$. To test the hypothesis is to determine if there is a significant difference when observing studying motivation before the experiment with the results of the calculation of independence observations after the experiment used a t test with a significant level $\alpha=0,05$.

\section{Results and Discussion}

Based on the results of data analysis and in accordance with the steps of research and development, the results of the study show that: First aspects of learning planning which include: (1) Identifying the topic of subjects to be given $65 \%$, (2) Making preparatory plans before learning $75 \%$, (3) Determine learning strategies according to the characteristics of students $55 \%$, (4) The accuracy of the selection of learning materials $65 \%$, (5) Systematic preparation of learning materials $45 \%$, (6) The accuracy of the objectives to be achieved $55 \%$ and (7) The suitability of learning media with the characteristics of students $15 \%$.

The two aspects of organizing learning consist of (1) Organizing learning citizens in the use of learning media $65 \%$ and (2) Organizing learning activities using interactive CDs and ebooks $25 \%$. The three aspects of the implementation of the learning process consist of (1) Submission of objectives to be achieved when opening lessons $55 \%$, (2) systematic presentation of material in learning $65 \%$, (3) The suitability of learning media with the characteristics of $45 \%$ students, (4) Stipulation use of media in learning $25 \%$, (5) Suitability of media with the needs of students $45 \%$, (6) Use of media in accordance with learning objectives $15 \%$, (7) Use of methods in accordance with learning media used $45 \%$, (8) Use of media in accordance with the characteristics of students 55\%, (9) Proportional use of time for opening, core and closing 35\%, (10) Suitability of subject matter with the experience of learning residents 55\%, (11) Learners are actively involved in learning $35 \%$, (12) The existence of reinforcement varies with appropriate and consistent time $35 \%$, (13) Giving conclusions at the end of learning $65 \%$, (14) The use of language in your learning media already understood $45 \%,(15)$ Media contains the substance of subject matter to be taught $25 \%$ and (16) The atmosphere of learning by using media is very dynamic $65 \%$

The four aspects of learning appraisal consist of (1) Learning media helps clarify learning material $15 \%$, (2) Accuracy of procedures and types of assessment of learning outcomes $65 \%$, (3) Appropriateness of assessment tools with material delivered 75\%, (4) Writing of items described in the grid and use language that is easily understood $55 \%$ and (5) Carry out an assessment of learning outcomes in the learning process $55 \%$.

Conceptual Learning Model The procedures adopted in implementing this blended learning model of learning, go through three stages, namely: (1) planning, (2) implementation, and (3) evaluation. Each of these stages can be explained as follows:

1) The Planning Stage in implementing this model involves several activities including: (a) Identification of learning needs, where tutors and students determine what material will be delivered in learning in accordance with the curriculum package B equivalent to junior high school. (b) Establish ICT-based learning media types, e-books and interactive CDs. Where the e-book media contains material about Social Science Lessons with the subject 
matter of Flora and Fauna Indonesia, while the interactive CD media contains material about English lessons with the topic of "Do you Enjoy To Trip".

2) The implementation phase of the blended learning tutor acts as a facilitator and acts as a learning resource to facilitate the learning process activities by: (a) delivering the objectives (competencies) to be achieved, (b) describing the material briefly; (c) explain the steps of using interactive e-book media and CDs, so as to provide learning experiences for students, with the use of media to facilitate citizens to learn to do motivation learning; and (d) conducting motivation learning using interactive e-book media and CDs in the implementation of package B.

The package B program students act individually or in groups collaborating with the tutor in carrying out learning activities with the steps: (a) listening to the description material carefully; (b) conducting learning activities using interactive e-book media and CDs according to the material taught by the tutor; (c) conducting motivation learning using interactive e-book media and CDs in this learning activity through the steps of: (a) turning on the computer, (b) carrying out motivation learning, (c) operating the computer to use the e-book and CD media interaction, and (d) planning the next phase of motivation learning. These steps are taken aiming to further enhance students' learning independence in actual learning.

3) The evaluation phase is carried out based on the criteria and instruments that will be used to assess the effectiveness of the learning model. Evaluation of model effectiveness is carried out through three stages of assessment, namely (a) assessment of learning outcomes (output); (b) evaluation of the model implementation process, and (c) evaluation of the impact of model implementation (outcome). Evaluation of learning outcomes is carried out to measure the effectiveness of learning success through initial testing (pre-test) to determine the level of mastery of learning material, carried out before the implementation of the model trials, and the final test (post-test) is carried out at the end of the whole learning process after it ends, through tests. Evaluation of the learning process is carried out to measure the effectiveness of the application of the learning model, through the distribution of questionnaires about students' opinions in the learning model developed. Evaluation of the impact of the implementation of the model (outcome), carried out on reflective activities to determine learning independence, is carried out through the distribution of questionnaires to students in group B.

\section{Implementation of Learning Models.}

The implementation of this learning model is to prove how much the blended learning model has an influence on increasing the learning motivation of package B program students, after which a two-tailed t test (two tails) is performed, with a significance of $\alpha=0.05$. Hypothesis testing of research conducted in this study, namely: Ho: There is no influence of the use of interactive CD learning media and e-books on increasing the learning independence of students in the package B program in the SKB of Bogor Regency. H1: There is an influence in the use of interactive $\mathrm{CD}$ learning media and e-books on increasing the learning independence of package B program students in the Bogor District SKB. Based on the submission of these hypotheses, data obtained from research results indicate that the posttest mean score is greater than the pretest mean score $(\mathrm{x} 1>\mathrm{x} 2)$.

Based on the calculation obtained tcount $=3.70$, then look for a table with degrees of freedom $(\mathrm{dk})=\mathrm{n} 1+\mathrm{n} 2-2$, which is $=18+18-2=34$. So obtained ttable $=1.697$. So that the conclusions of tcount $=3.70>$ ttable $=1.697$ with a significant level of 0.05 . 
Thus Ho is rejected and H1 is accepted which means there is an influence of the use of interactive $\mathrm{CD}$ learning media and e-books on improving student learning motivation of package B programs in the Bogor District SKB.

Based on the data obtained, that the average pretest score of 18 students in the experimental group was 54 where the highest value was 77 and the lowest value was 41 . This shows that the level of motivation was classified as Less. While the mean value obtained by the experimental group was 81 where the highest value was 101 and the lowest value was 67 . Overall, motivation to learn after being treated was classified into the Good category. Thus an increase in the average pretest and posttest values of students from 56 to 81 . So the increase in the average value of 25 points or $47.8 \%$ can be categorized in the category of Good Enough.

So by paying attention to the results of testing the hypothesis and the results of the difference between the pretest and posttest values it can be concluded that the effective learning model of blended learning in increasing the learning motivation of package $\mathrm{B}$ program students in the SKB of Bogor Regency.

\section{Discussion}

Research on the development of learning models in its application, has obtained findings that indicate the effectiveness of meeting the learning needs of students in equality in package $\mathrm{B}$ in increasing their learning motivation. Therefore, the significance of the results of the study of the development of this learning model has implications both theoretically in increasing the repertoire of knowledge, as well as practically for operational policies that can be applied in the implementation of package B program learning in the Bogor District SKB.

In the development of community education, this learning model contributes to strengthening learning theories that can add to the treasury of knowledge in the dimensions of learning in equality education. Learning as a process of increasing human resources is very important (human capital), meaning that learning programs are designed and implemented, basically aimed at developing the ability of individuals or groups, in order to improve their intellectual [15].

The blended learning model of learning with the development of interactive CD media and e-books is used as a strategy in learning, which has actually been able to increase the motivation of students to learn in equality education package B in the Bogor District SKB. Appropriate empirical findings the application of this model shows its effectiveness for the fulfillment of learners 'learning needs in an effort to increase their motivation to learn, so as to foster learning motivation and creativity, thereby increasing their learning achievement in meeting the needs to increase students' learning motivation. In turn, it will support the effectiveness of the implementation of equality education specifically package B in the Bogor Regency SKB.

The blended learning model developed, in its implementation, has been shown to be effective in increasing the learning independence of package B program students, and can be accepted as an alternative to the development of more contextual, effective and efficient learning programs in accordance with the conditions of the students. In its implementation, the learning model developed shows effective in increasing the independence of learning of students, so that it can be used as an alternative in helping to improve the ability of package B students in the SKB, so that the implementation of community education programs develops towards a higher quality, and effective. SKB generally must be supported by an adequate number of tutors, but the quality of learning is still weak. Based on this, it is necessary to strive to improve the quality of learning better and more effectively. 
Referring to the blended learning model as an effort to increase motivation to learn, the role of tutors based on theoretical and empirical studies in learning activities functions: (1) growing students' awareness as learners and their importance to increase motivation in learning; (2) helping students as learners to be able to develop their potential, according to their talents and interests; (3) increase students' awareness of the importance of quality themselves efficiently in order to achieve achievement.

Another function of Information and Communication Technology in the context of classroom learning is as a tool or means used to make improvements / improvements to learning activities. So that students become more autonomous and critical in dealing with problems, which ultimately lead to increased student learning outcomes. Information and Communication Technology can and truly helps students develop all types of skills, ranging from very basic levels to higher levels of critical thinking skills [16].

Based on these functions shows the tutor as a learning agent, especially in the implementation of the package B program in the Bogor Regency SKB towards better learning. This is in accordance with one of the principles of lifelong education according to Sudjana [17], that community education is developed based on one of the principles including, learning activities to acquire, renew, and / or improve the knowledge, attitudes and skills that are owned by community members according to continuous change throughout life.

How tutors can provide quality learning, so that SKB is still able to provide optimal learning services to students, including equality education services package B. The alternative is to equip teaching skills using practical media in their innovative learning through blended learning.

The findings of this study indicate that the mean value of learning independence of package B program students has increased quite well. This is indicated by the acquisition of learning outcomes that show positive improvement using interactive CD media and e-books in tutoring, as well as enthusiastic student responses to the application of the developed learning model. On the basis of the findings in this study, the learning model developed is said to be effective in increasing the learning motivation of package B program students in the Bogor District SKB.

\section{Conclusion}

Assessing from the above explanation, it is concluded as follows:

1) The use of ICT-based media in learning the package B program has not reached its maximum potential yet as limited number of computer hardware. Thus, during face-to-face session, the use of media by tutors is still considerably low engagement.

2) The conceptual model of blended learning which utilises interactive $C D$ media and ebooks in teaching process. Additionally, this method increases students' motivation to learn in package B program in SKB.

3) The results of the implementation of the blended learning model developed were quite effective, which had an effect of $47.8 \%$ on increasing the motivation to learn package B program students on the SKB

\section{References}

[1] Sutisna, A. (2016). Pengembangan Model Pembelajaran Blended Learning pada Pendidikan Kesetaraan Program Paket C dalam Meningkatkan Kemandirian Belajar. JTP-Jurnal Teknologi Pendidikan, 18(3), pp.156-168. 
[2] Sudrajat, A. (2011). Mengapa Pendidikan Karakter? Jurnal Pendidikan Karakter, 1(1).

[3] Surya, M. (2006). Potensi Teknologi Informasi dan Komunikasi dalam Peningkatan Mutu Pembelajaran di Kelas. Makalah Dalam Seminar Pemanfaatan Teknologi Informasi Dan Komunikasi Untuk Pendidikan Jarak Jauh Dalam Rangka Peningkatan Mutu Pembelajaran, Jakarta: Pustekkom Depdiknas.

[4] Manik, D. I., andLubbers, C. A. (2016). Use of ICT and Traditional Agriculture Information Sources by Bangladeshi Farmers. QRBD, 267.

[5] Havelock, R. G. (1991). Change The Agent's Guide. New Jersey: Educational Technology Publications, Inc.

[6] Wahyono, B. (2016). Indikator Motivasi Belajar. Retrieved December 16, 2019, from http://www.pendidikanekonomi.com/2014/10/indikator-motivasi-belajar.html

[7] Lomicka, L., \& Lord, G. (2007). Social Presence in Virtual Communities of Foreign Language (FL) teachers. System, 35(2), pp.208-228.

[8] Thorne, K. (2003). Blended Learning: How to Integrate Online and Traditional Learning.

[9] Bersin, J. (2004). The Blended Learning Book Best Practices, Proven Methodologies and Lesson Learned. San Fransisco: John Weley.

[10] Aly, I. (2016). Comparison of Students' Performance in a Managerial Accounting Course Taught in Blended Learning, Traditional Classroom, and Online Setting. Quarterly Review of Business Disciplines, 2(4), pp.325-336.

[11] Chen, W. S., \& Yao, A. Y. T. (2016). An Empirical Evaluation of Critical Factors Influencing Learner Satisfaction in Blended Learning: A pilot study. Universal Journal of Educational Research, 4(7), pp.1667-1671.

[12] Isa, Y. (2015). Pengembangan Model Blended Learning Mata Kuliah Perencanaan Pembelajaran Teknologi Informasi Dan Komunikasi. JTP-Jurnal Teknologi Pendidikan, 17(2), pp.73-83.

[13] Sugiyono. (2008). Metode Penelitian Pendidikan:(Pendekatan Kuantitatif,Kkualitatif dan $R \& D)$. Bandung : Alfabeta.

[14] Iskandar, M. P. (2013). Metodologi Penelitian Pendidikan dan Sosial. Jakarta.

[15] Kamil, M. (2007), Teori Andragogi, dalam Ilmu dan Aplikasi Pendidikan. Bandung. Pedagogiana Press.

[16] Mac Kinnon, Soledad. (2005). Technology Integration in the Classroom: Is There Only One way to Make It Effective (http://www.techknowlogia.org).

[17] Sudjana D. (2005), Strategi Pembelajaran dalam Pendidikan Luar Sekolah, Bandung: Nusantara Press. 